Polar Record

www.cambridge.org/pol

\section{Research Article}

Cite this article: Sörlin S. Wisdom of affect? Emotion, environment, and the future of resource extraction. Polar Record 57(e27): 1-9. https://doi.org/10.1017/S0032247421000097

Received: 16 January 2021

Accepted: 26 March 2021

Keywords:

Extractivism; Natural resources; Arctic

humanities; Environmental history; geopolitics

Author for correspondence:

Sverker Sörlin, Email: sorlin@kth.se (c) The Author(s), 2021. Published by Cambridge University Press. This is an Open Access article, distributed under the terms of the Creative Commons Attribution licence (http:// creativecommons.org/licenses/by/4.0/), which permits unrestricted re-use, distribution, and reproduction in any medium, provided the original work is properly cited.

\title{
Wisdom of affect? Emotion, environment, and the future of resource extraction
}

\section{Sverker Sörlin (1)}

Professor of Environmental History, Division of History of Science, Technology and Environment, KTH Royal Institute of Technology, SE-100 44 Stockholm, Sweden

\begin{abstract}
The "Arctic Uchronotopias" special issue of Polar Record is an important contribution to scholarly reflection on resource extraction. The ideas, perspectives, and empirical cases that we encounter have significance for extractivism wherever it takes place, both inside and outside of the Arctic region. To see extractivism through an Arctic lens is particularly useful since it brings up many of the issues that are often at stake in extraction activities, but not always at the same time: geopolitics, transboundary relations, environmental and climate impacts, cultural and natural heritage, indigenous relations, rights issues, local and regional development, and lives and fates of communities. Above all, these papers bring out the full spectrum of issues and tensions related to ongoing major global shifts, such as the Great Acceleration and Overheating, and those transformations of which resource extraction forms a major part. The research presented in Arctic Uchronotopias demonstrates that affect and emotions have explanatory value in the geopolitics of Arctic resource extraction. It also shows that emotional and cognitive experience and wisdom carry values and properties that conventional Environmental Impact Assessments and other technologies of evaluation and decision-making can capture.
\end{abstract}

To my mind, the Arctic Uchronotopias special collection of Polar Record is among the most important contributions that we have seen in recent years in scholarly reflection on resource extraction. This is true for the Arctic in particular, since the contributions, with one exception, on Australian mining towns (Askland, 2021) focus on the global far North, in particular on Greenland and Fennoscandia. It is also true in a more general sense. The ideas, perspectives, and empirical cases that we encounter in these nine articles (the Introduction included; Thisted, Sejersen, \& Lien, 2021) have significance for extractivism wherever it takes place, not just in the Arctic. To see extractivism through an Arctic lens is useful since it brings up so many of the issues that are often at stake in extractivism, but not always at the same time: geopolitics, transboundary relations, environmental and climate impacts, corporate logics, cultural and natural heritage, indigenous outlooks, rights issues, local and regional development, and lives and fates of communities.

Above all, these papers bring out the full spectrum of issues and tensions related to the ongoing major global shifts and transformations of which resource extraction forms such an important part. The last two generations have not only seen "the Great Acceleration" and planetary scale human impact of the Anthropocene (Adeney Thomas, Walters, \& Zalasiewicz, 2020; Steffen et al., 2015). They have also experienced what Thomas Hylland Eriksen (2016) has called "Overheating," the massive increase of speed in an ever more entangled geo-socio-anthropological sphere of population, mobility, migration, circulation of goods and services, financial streams, climate change and - not least - the dramatic growth of extractive industries that feed the global metabolic hyper-loop with more and more minerals and fossil energy. This does not mean that the world is set on a unilinear trajectory of future history. On the contrary, history is still fraught and full of tension and controversy. The future is still open and unknown, a remark perhaps more ostensibly meaningful in the early 2020s than it has been for some time. Transitions and tipping points ahead are likely.

These papers thus reflect a refreshing new balance of argument that is emerging on resource extraction, which makes them speak to the historical moment we are in. In doing so they allow us to sense that resource extraction is itself part of the change. Clearly, on the surface the papers demonstrate that resource extraction still revolves around classical conflicts of interests. There are actors outside the region, typically transnational companies that operate on market logics that engage and often provoke interests closer to the site of controversy. Local communities, often partly or wholly indigenous, are affected. They will probably suffer from the extraction, at least over the long term and in some communities and cultures, although some of their members will perhaps get jobs and better services in the short-to-middle term. In this respect, these papers may seem like so many case studies we have been reading from all over the world since boom and bust mining became a trope of socially engaged reporting and research in the 19th 
century. We know already that restraining factors such as "the environment" (Warde, Robin, \& Sörlin, 2018) and sustainable development did climb on the agenda in waves of new demands on extraction since the Cold War and with growing awareness of the Arctic climate crisis since the 1990s. The same is true for indigenous rights (Coates, 2018; Fondahl \& Wilson, 2017; Keeling \& Sandlos, 2015). Oil, gas, and mining companies have even been ranked in relation to indigenous rights in the Arctic (Overland, 2016), and considerable research has been pursued to identify and articulate ethical, social, and anthropological standards of extraction.

\section{The extractivist regime of industrial modernity}

On further examination, however, these papers do more than that. They offer a new interpretive framework that moves the understanding of what is actually going on when societal processes of decision-making on extraction are taking place. Perhaps most importantly, they show that such processes - procedurally often strictly regulated - engage so many more dimensions of what it means to live near and experience firsthand the spatial and temporal effects of extraction. These effects lead long lives, from way before mining has commenced, to long after a mine is abandoned or, for that matter, any resource exhausted. Minerals and energy are becoming "resources" - so defined according to the evolutionary logic that has been known in the literature since almost a century (Bridge, 2009; De Gregori, 1987; Zimmermann, 1933). They are also proposed to become extracted somewhere to serve some purpose that is nearly always elsewhere, thus entering into complex spatial relations and with a multiplicity of significant voices speaking to the issues from a large number of entry points. In that, they are also becoming social and cultural. Only rarely does the initiative to extract come from inside the community, but as soon as the issue comes on the agenda, the decision-making process starts, almost like a choreography with standardized roles and rules.

What these papers show somehow inadvertently is that this choreography of entering, pursuing, and leaving extraction is not at all standardized. It plays out not just at the order of protocol but along lines that are multiple, entangled and refute planning in the conventional sense. The voices we hear are manifold and diverse. Legitimate expertise is hard to define. There is also diachronic change involved. In other words, the entire phenomenon of making up our social minds about whether or not to extract and where is historical and always still evolving.

Until quite recently, the extractive side of this game had the obvious upper hand. When the legal frameworks of mining, and perhaps especially Arctic mining, were conceived in the early days of industrial modernity, extraction of minerals was almost exclusively seen as beneficial. Counterarguments ranged from ontological skepticism (we are not sure the spirits will like it), to lack of contextual understanding (we do not see the point of extracting minerals here), to a notion of primordial right to the land (we were always here and it is ours) all across to plain fear. Arguments were rarely taken seriously by Westerners, including in the Arctic (Cruikshank, 2005). Fear and despair were appropriate, mining practices were often oppressive and cruel. Pain and suffering, however strong and real among indigenous communities that had already seen what mining could mean to them and their animals and livelihoods, did not get a proper social articulation. Early examples are the Swedish Nasafjäll mining case in the 17th and 18th centuries (Bromé, 1923) or in the Torne River Valley on the current Finnish-Swedish border (Nordin \& Ojala, 2015, 2020). From southern centers, mining was regarded as the epitome of civilization and progress. Early extractivist ideologies ranged from mercantilism in the 18th century with import substitution and export income as a key goal underpinning expansionist northern strategies in Fennoscandia (Magnusson, 2015; Sörlin, 1988). Economic liberalism and industrial socialism in the 19th and 20th centuries were equally confident of the virtues of mineral exploitation, and it was during this period that most Arctic states introduced and enforced mineral legislation and presented ambitious schemes for resource extraction, terrestrial as well as marine (Sörlin, 2017). Regulation was slack, based on the assumption that the positive effects of mining were overwhelming.

Resource extraction grew to global significance as part of a particular version of industrial modernity, which rested on an assumption of virtuous transformation of raw materials to goods and societal value with little harm of any kind, and the unquestionable harm wrought on local communities was justified with progressivist ideologies. In retrospect, it is easy to see how this regime worked in parallel with other characteristics of industrial modernity such as a high valuation of technology, rationality, an anthropocentric logic, and an emerging resource nationalism in the Arctic (Childs, 2016; McCannon, 2012), linking natural resources to the prowess and prosperity of the nation and the welfare of its citizens. It was also a period of generalized racism and ideas of Western and white supremacy with little or no respect for indigenous populations and their interests and livelihoods (Broberg \& Roll-Hansen, 1996; Fur, 2013; Fur \& Hennessey, 2020; Gaski, 1993). There was a Scandinavian colonialism, and a significant part of it had a northerly direction (Naum \& Nordin, 2013). Ethical or political constraints on mining were weak. Pressure on mineral sites was therefore relatively low, although instances of Arctic resource bonanza, especially on maritime resources such as whale and seal but also on minerals, coal and oil in Alaska, Svalbard, North Western Russia, was a recurring reality fairly early (Avango, Nilsson, \& Roberts, 2013), resembling the quest for colonies during high imperialism.

Since the late 1800 s, resource extraction has been a continuous, large, and growing phenomenon. This industrial modernity regime continued more or less uninterrupted during the post WWII decades and even after the Cold War ended in 1989 and into the 21st century. But, although the legal structures have only changed moderately so far, other framing conditions have shifted more and are now starting to impact on the decision-making processes. It is characteristic of the ongoing changes that they started on the discursive level, which is where the Arctic Uchronotopias papers are particularly convincing.

Industrial modernity accelerated dramatically during the 20th century and did so underpinned by a massive growth in the production and consumption of fossil energy. It is now changing rapidly; in fact, it is in the middle of a profound crisis. The fossil-fueldriven world as we know it is questioned and in many parts of the world already taking a downturn, led by global ambitions to curb climate change and reach the 17 UN Sustainable Development Goals. Extractive modernity came with a particular kind of societies, based on values linked to gender-, ethnic-, and social hierarchies and with largely unsustainable practices. As this modernity is challenged, political and cultural tensions have grown around extractive industries. They go far beyond those we saw in the past, captured by concepts such as "preservation" - the protection of places and emblems of nature as precious or sacred - and 
"conservation" - advocating wise, responsible use of vulnerable resources and lands (Josephson, 2014; Hays, 1959; McCannon, 2012; Nuttall, 1998).

\section{Challenging the "groundwork of abstraction"}

The Arctic Uchronotopias papers, and its editorial team, have found the precise crack to enter into these acutely relevant tensions appearing at a critical turning point of Arctic history. The title of the special collection stems from German historian, Hagen SchulzForberg (2013), who used the Russian semiotician Mikhail Bakhtin's concept chronotope, combining space and time, to suggest a particular form of narrative of the ideal. By invoking at the same time the idea of utopia, he constructed the Uchronotopia concept to signify such a future ideal time-place narrative (Thisted et al., 2021). The editors have perceptively identified emotions as an important category in such future narratives, both in the narratives themselves and in their social circulation. There is no lack of projected, desired, or hyped futures in the Arctic; they abound and compete with each other (Wormbs, 2018). Futures are anticipations with an agency that is active now, enacting and foreboding. They are deeply political, and they play out in different registers, including affect, fundamentally because extractivism means interventions and transformations, and provoke and mobilize emotion, often pro or contra.

Collectively, these papers make us see a discursive logic that is transcending the confines of the existing extractivist regime, and it may be worthwhile observing more carefully how they do that. First, the cases presented bring to light several new aspects of the extraction decision-making process. One is an understanding that the pro-extraction argument has been built precisely through various discursive technologies. In her study of a mining project by the Tana river in Norway's Eastern Finnmark, Marianne Lien (2021) productively calls these technologies a "groundwork of abstraction." What this "groundwork" does is to move the site-specific embeddedness of the materialities under discussion into the realm of calculability and comparability. These technologies turn experiences of nature and landscapes into numbers and indicators. This is in line with research on quantified approaches applied to reduce complexity and "globalize" management concepts and technologies. Hence, they seek to establish level playing fields with less friction for transnational investment, mobility of labor, also softening claims on security and welfare rights (Ernstson \& Sörlin, 2013; Haikola \& Anshelm, 2019; Porter, 1995). Knowing about that process means a better chance to relate to it and find ways of dealing with it.

Increasingly, these abstractions are also known, perhaps especially among the critics of extraction. Gro Ween (2021) in her fieldwork on the same site as Lien finds local informants that are fully aware of the rhetorical properties of the numbers employed. Her research shows that there is an awareness among extraction opponents that the decision-making process favors and even demands calculable properties while it fails to take local experiences into account. Similarly, there is a high level of articulation of cultural heritage in defense of local sites and landscapes against exploitation, for example stones of worship, sieidi, as demonstrated by Dag Avango and Britt Kramvig (2021). Language, words get significance in this regard, as carriers of experience-based knowledge, providing a contrast to numbers. Meahcci is a word for landscape, related to movement and land use. Meahcci connects the land and its people and is a word that links user rights with particular places and resources. Avango and Kramvig observe in particular how it is distinct from luondo, another word for land, which refers to abstract nature not in use (Riseth, Solbakken, \& Kitti, 2010; Ween \& Lien, 2012). Heritage can of course also be a resource in its own right, providing yet another barrier to extraction, which threatens to ruin heritage (Avango \& Roberts, 2017). These examples prove an awareness among local actors engaging in public discourse on extraction and a process of discursive mobilization ongoing whereby the narrative and spatial arrangement of objects and places will affect the perception of what is at stake and what is a desirable outcome.

A further aspect of the discourse is new constraints linked to environment. Gradually environmental impact analyses (EIA) have become the norm over the past half century. EIAs are tricky, often a technology of abstraction themselves, obscuring real-world elements to quantifiable, discreet, and moveable parts. Social and environmental impact assessments of extractive projects tend to favor topics that are highly formal and technical and often miss what local communities perceive as the central issues or total impact (Koivurova, Lesser, Bickford, Kankaanpää, \& Nenasheva, 2016). Even schemes labeled "green" are sometimes managed in ways that disfavor indigenous groups (Retten, 2021). More widely, fact-gathering enterprises covering the entire Arctic region likewise tend to hone in on what is measurable, disregarding societal concerns and policy. Such enterprises are conducted within an extractivist regime that itself typically goes unquestioned (Oppenheimer et al., 2019; Sörlin, 2018; Wormbs \& Sörlin, 2017). Nonetheless, the assessments provide arenas of debate and potential friction that communities can make use of, despite much frustration, as for example Marianne Lien (2021) makes clear. There are also now better attempts to include social and cultural impact schemes to get more voice to local communities (Novikova, 2017; Papillon \& Rodon, 2017; Wilson \& Stammler, 2016).

Emotion work is entangled and in that sense closer to the "lifeworld" experience. Entanglements of affect reflect social and environmental relationships that are hard to reduce in local communities where livelihoods too are entangled, seasonal, and bound to landscapes in complex ways. Impacts are themselves entangled, multilayered, and interacting. A concept used to capture these entanglements and mutually amplifying impacts is "multiple pressures" (Österlin \& Raitio, 2020, Rosqvist, Inga, \& Eriksson, 2021; Sörlin, 2021). The concept has been applied in research on mining regions in northern Fennoscandia (Kiruna and Gällivare), and it is noticeable in western Greenland in the attempt to understand conflicts between mining, tourism, and subsistenceand recreation-based activities (Nuttall, 2017).

In several of the Uchronotopia cases, a common theme is the frustration in local communities of the lack of understanding for complexities in the relationships between land and livelihood. Feelings rise when land is irreducible to a single site commodity, as in mining, but consists of an entire landscape of living resources, memories of past use, and potentials of future use. The pattern is not unique to the Arctic and not to mining. On the contrary, it is a very common consequence of the ever-increasing impact of longdistance resource extracting interventions on landscapes and ecosystems across the world. In the Arctic, this critique of EIAs with suggested indigenous-led knowledge gathering processes now forms an important backdrop of mining debates (Larsen \& Nilsson, 2017; Larsen, Raitio, Stinnerbom, \& Wik-Karlsson, 2017; Lawrence \& Larsen, 2017). 


\section{Tools of affect: flirting, happy objects, new histories}

These carefully researched texts allow the reader to get in full contact with a range of issues that bring to bear on decisions to extract or not extract a resource and if so how the extraction should be conducted. What made this analysis possible is the theoretical approach that the authors have taken from the affective turn in the humanities and social sciences (Clough \& Halley, 2007; Seyfert, 2012). Importantly, the papers do not use emotions in the old-fashioned sense, placing them squarely in the camp of the vernacular or "tradition." Hence, emotions are not just that which affect those who are threatened and vulnerable and defend their interests/cultures/lands/ecologies/beliefs in relation to the cynical and rational tactics of the extractive industries. On the contrary, we learn that emotions are everywhere, and they play out in interactions.

One of the strongest impressions that I take from this special collection is the account of the annual meetings of the Prospectors and Developers Association of Canada (PDAC) in Toronto 2016 to 2019, presented by Lill Rastad Bjørst (2021). She reads the interaction between the Greenland representatives and the mining and prospecting companies as a flirtation game. Bjørst takes her cue from sociological work with roots in Georg Simmel's ideas on die Koketterie (Hoffman-Schwartz, Nagel, \& Stone, 2015) making the observation that the flirtation stands "at the boundary between imagined and realised desire." She cites Paul Fleming (2015), who talks about flirting as a "play" performed between one person and another who is at the same time "an instrument and... a partner"(21). Bjørst says this flirting game is a good way of understanding the exchanges she observes in the PDAC when Greenland enters: a new, "young" (in that context), presumably attractive potential partner on the annual mining circuit. Making her observations in Toronto, Copenhagen, Nuuk and using art and multiple forms of media, she calls her method a "multi-site ethnography," pointing out that much of what is going to become significant in Greenland plays out elsewhere, in a distributed sphere of influence, with vague connections to the democratic foundation of the Greenlandic representation.

Equally illustrative is Kirsten Thisted's (2021) elaborate analysis of the post-2009 moment in Greenland. That was the year when Denmark granted her former colony Self Government, after becoming an "equal part" of Greenland in 1953, receiving Home Rule in 1979, and expecting full independence to be the logical next step further into the 21 st century. It was also a moment of affect. The Greenland Prime Minister Aleqa Hammond, the second PM to assume office after 2009, seized the moment to leave the conventional script of the subordinate, postcolonial subject, which prescribed gratitude toward the former colonizer for protection and support over generations. Instead, she now talked of a "new beginning," in the sense of the foundational figure of German Begriffsgeschichte, Reinhart Koselleck: a Stunde Null when history reboots and starts afresh (Koselleck, 1979, 2002). Its foundation is a promise of future extraction of minerals, especially uranium.

Hammond and Greenland were breaking loose from an old and unproductive relationship. New, better, wealthier, happier relations are lying ahead. Changing the future means, again rooted in Koselleck's thinking, that a new history is needed, to fulfill what Sara Ahmed in her work on emotional economy called "the absent presence of history" (Ahmed, 2010). What is in store for Denmark is instead a sense of loss, a "postcolonial melancholia," Paul Gilroy's evocative concept to describe Great Britain after empire
(Gilroy, 2005). Bigger empires already crumbled, now it is Denmark's turn as its vast North Atlantic empire wanes and Greenland strikes up new, more promising relations. Ultimately, by implication it is a loss of power and of Denmark's future status as a legitimate Arctic power.

In Thisted's reading, Hammond used the moment creatively to collect props (a piece of uranium) and tangible new foreign relations, specifically with China for which mineral-rich Greenland was precisely the right kind of partner. In the words of Sarah Franklin (1997), Thisted convincingly suggests, Hammond applied a "hope technology" in her collection of "happy objects" that could be used to signal the joyful beginning of a new era for her vast region and to build the promise of a future independence from the Kingdom by the middle of the 21 st century. Uranium is, at least in the moment of emotional secession, such an object.

Frank Sejersen (2021) talks about Hammond as a "broker of hope," hereby connecting several theoretical approaches. One is precisely the affective reading of Koselleck's notion of new beginnings. There is a "current us," Sejersen argues, that is marked by the colonial legacy and represents an undesirable state that the born (or reborn) Greenlandic nation wants to leave behind. In this historical moment there is the prospect, even an expectation that a "future us" will appear. In the gap of the present, in between that past left behind and the emerging desired "Uchronotopia," the broker of hope can step in, articulate, and conjure up the desired future. It also relates to what Anna Tsing has called an "economy of appearances," based to a large extent on the growth and spread of instantaneous financial markets and the hopes and speculation that findings of minerals can create. These emotions can be very strong, and equally strong can the anger become if the finding does not live up to expectations (Tsing, 2000). What Sejersen does is to place the broker of hope precisely in that moment after the finding, which in Greenland's case was not a new physical finding in the ground; both uranium and other minerals have been known for a long time but deemed unattainable, but before the realization. It was not a geological opportunity seized, but a political crack opening with Self-Government that would make new partners available and Greenland herself attractive.

\section{Community and the agency of affect}

Affect is historical. The sentiments that a piece of nuclear mineral evokes will be different depending on when and where it is presented. Post-Fukushima, it is hard to brandish it in Japan or, for that matter, most places around the world (Pritchard, 2012). There are also passages in the Uchronotopia papers where this comes across. For example, what should be the status of "community," this cherished thing, which, however, is rarely a property owner, even less a company. Everybody acknowledges it as important. But then what? What is a community? Anne Mette Jørgensen (2021) scrutinizes the concept, called upon in Arctic policy contexts more than possibly anywhere else in the world. When a word diffusely appears as a kind of reference taken as a given, one has reason to be suspicious. The suspicion is warranted, she finds, supported by Gerard Delanty's classical theoretical work on community (2003), now two decades old, and by Margaret Wetherell (2012) on how affective communities form.

Jørgensen's work presents communities in North Western Greenland and in Swedish Norrbotten county, both affected by mining projects. In the Norrbotten case, a diverse range of forest dwelling households were encountering the expansion of a copper 
mine into lands where they lived, which caused them to come together and articulate their interest. In Greenland, the Qullissat mine was halting and turning into a post-extractive phase since the late 1960s. The small town of Qullissat was literally dismantled by the colonial authority around 1970, and a diaspora formed, many of which assembled in the neighboring bigger town of Ilulissat. They at first stuck with their former, now abandoned community as a "tragic object." Over the years, however, some of them started to re-evaluate their past forming a sense of community that shared a future. What comes across as important is how affect determines the capacity to cope. In both cases, communities came together through active usage of narratives and temporalities. Individual households and groups that in the past were geographically and socially dispersed interacted and integrated through a mobilizing process as they related their own fate affectively to the big mine, either letting them down or lurking on their doorstep.

Jørgensen calls this process "communitification," a complex word, but one that speaks about communities as not fixed but rather becoming in a process of shifting relationships and forging identities. Her analysis resonates in many ways with those of Bjørst, Sejersen, and Thisted. She argues that the communities thus formed employ narrative strategies of "uchronotopia," referring, like most of the Uchronotopia papers, to Hagen SchulzForberg's (2013) concept. These communities aimed "towards better futures by narratively breaking with the past." The agency of the communities, she argues, owes a lot to the intensity of their affective economies, a "symbolic capital that may hold considerable potential for creating desirable futures.” Jørgensen's paper makes it clear that many communities also derive their agency from what might be called a critical situation. They realize that they have to articulate their position and present a case precisely because of their strong emotions of discontent and anger. It is in that moment they start collecting their evidence, making explicit their knowledge and interests, and forming alliances with outside agents.

The power of this analysis lies in the way it argues that affect and rationality are coproduced. It occurs to me that the analysis presented in this and in most of the other articles will have much to offer to anybody who wants to engage in extractive conflicts wherever they are. It is very hard to even draw the line between the rational and the affective, which is yet another beauty of these papers. This will not make it necessarily easier to come to conclusions in mining conflicts, but the imbalances in the decision-making processes may be redressed. There are many insights to be drawn from the papers that will surely inform discussions, and possibly regulation, of decision-making in the future. It also, as a kind of bonus, becomes apparent that community is a slippery concept. On the one hand, "community" remains this almost post-political concept that could always serve as a harmless selfexplaining reference. On the other hand, it has an innate attraction as what Zygmunt Bauman referred to as a "warm" place, in contrast to "company" or "society," which you may not like or fit in. Community is "always a good thing" (Bauman, 2001). It has nostalgic properties, says Delanty (2002), especially in times of transnationalism and hyper-individualism, which again tends to turn it into a post-political space.

As the empirical cases show, there is, however, a potential content that is tangible, real and can feed agency. Community, it could be argued, is a smaller version of the large community of the nation, an "imagined community" in Benedict Anderson's (1983) famous concept: people who share the same experience and sphere of awareness as you but who you can never meet face to face. Both the local and the national communities promise Gemeinschaft in Ferdinand Tönnies' language. Both require elements of construction - narratives, myths, a sense of "us" that can travel from past to present, and on into a "future us." Similar meaning-making activities take place. Still, a nation is more relativistic, it has a voucher character. You can opt out, choose not to be part, at a reasonable cost, and still belong in some technical sense, for example through civic rights and a passport. A community you either belong to or distance yourself actively from, at some risk.

\section{Affect and emerging temporalities}

One thing that has struck me in these papers is how the emotional new beginnings and their approaches to past, present, and future are predicated on even grander narratives. Although it is clear how all voices heard in the controversies are linked to some kind of selfinterest, more or less legitimate or at least understandable, it is also evident that they gain their narrative strength and can communicate confidence only insofar as they are in line with a wider perception of where the world is going. They must locate themselves in this world of possible directions, and they must resonate with emerging temporalities that seem likely. It seems as if Hammond, the Greenland PM, on that score had not really built her case well enough in the beginning. It became obvious to her that uranium may not be the happy object it seemed at first. Not only because of the uncertain future for nuclear power, but also because of the sensitive nature of becoming dependent of China as a super power.

Here is also the affective backdrop to the failed attempt by the US President Donald Trump to purchase Greenland from Denmark in 2019. The attempt was passionately rejected in both Denmark and Greenland, including by the Danish government, but not as wild an idea as it may have seemed. The USA tried to buy Greenland several times before and indeed did purchase the Danish West Indies in 1917. It was likely the fearful prospect of China de facto dominating the world's largest island and serving as the key to the Arctic and the Western hemisphere that served as an underlying strategic argument (Wendel-Hansen, 2019). Lill Rastad Bjørst (2021) shows how the mining companies too are part of the emotional economy and need to make similar claims on directions and temporalities. Presenting their mining prospects to local and national audiences, it is very little talk about money to shareholders. In the rhetoric, affective futures matter most.

What the Uchronotopia articles show is, therefore, how the interplay of interests is not just simply a marshalling and counting of rational arguments. If it were only a matter of calculable arguments, extraction issues would be much easier and its tensions less fraught. Emotions make mining conflicts much more unforeseeable. Sentiments can move away from what seems obviously the right thing to do. Potentially they can reach very far, indeed much farther than arguments of more immediate interest to the parties with stakes in the conflict.

In that regard, the emotional economy also puts a question mark by the "stakeholder" concept, which has been much used in managing social and environmental conflicts over the past decades, typically to show how business and sustainability can align (Freeman, Pierce, \& Dodd, 2000; Hörisch, Freeman, \& Schaltegger, 2014). The stakeholder concept has served, perhaps inadvertently, the purpose of limiting the controversy to those with acknowledged rights to speak because of their stakes, as landowners, residents, community members. The universe of 
stakeholders is limited and can be defined according to custom or principle. The economy of affect has permeable boundaries and hence the emotional conflict can travel far beyond the actual site of the controversy.

\section{Pushing the limits of rationality: the wisdom of affect?}

The articles assembled here suggest that emotions actually trump "rational" arguments. In that regard, the analysis is in line with a broader orientation toward a politics of emotion emerging alongside the rise of neoliberalism, especially after the millennium. Much of this affective politics has been a project on the political right, and one of its homes has been right wing populism, which typically has been a pro-extractivist camp in politics in many places around the world. Coal miners from Silesia in Poland to Queensland in Australia to the Appalachians in the USA tend to support extractivist and nationalist politicians (Allen 2020, 2021; Glassheim, 2016; Hylland Eriksen, 2018). This is just an observation, or perhaps a reflection, but it begs the question what the politics of mining emotions - to use the term launched by the editors (Thisted et al., 2021) - might be in the Arctic context. What will happen to a concept such as "progress" if emotions get a wider influence? What about justice? Or power, and thus also the limitations of power? Will they (have to) change?

We once believed that rationality and sound argument were the precondition for such grand and value-laden words to be adhered. One could also argue that the "groundworks of abstraction" and stringent decision-making processes based on calculation are designed precisely to uphold the normative structure of a democracy that must not favor certain groups or interests. There is work to be done here in order to maintain the normative structure of democratic modernity based on transparent argument and at the same time include the reasonability or soundness, if not wisdom of affect that these papers bring out. The pro-extractivist abstraction has gained the upper hand to an extent that is no longer reasonable or wise. It is even irrational when, time and again, it is demonstrated that it is perfectly in line with existing regulation to allow extraction of fossil fuels in the Arctic (Alaska, Barents Sea) that with absolute certainty will contribute to ruining our common future (Arctic Today, 2020).

One item on such an integrative research agenda will surely be to ask the question how it can be that resource extraction got this privileged position in the modern world and why it is allowed to now expand rapidly into the warming and ever more accessible Arctic? Another major effort would be directed to a reform of decision-making processes. It would also be interesting to think about international law and how it might be applied to protect communities and environments (Lawrence \& Åhrén, 2016). Increasingly, legal action is taken to probe the justification of resource extraction, often linked to international agreements, for example on $\mathrm{CO}_{2}$ emissions (Ebbesson, 2020/2121; Jarvis, 2019; Pryser Libell \& Bryson Taylor, 2020). Ultimately, both the limitations and reach of private property and the territorial sovereignty of states will need to be included into these discussions, alongside with issues of rights to customary users of land. This may seem a daunting, perhaps utopian research agenda, but it is in the long-term interest of all of us and the planet to ask questions that stand in parity with the effects that resource extraction, circulation, use, and emissions cause.

The contributors to this special collection may not have conceived such ambitious outcomes of their work, however advanced and challenging, but it speaks to the virtues and qualities of their papers that these ideas have dawned on me reading them. They have demonstrated very convincingly that affect is (also) virtuous, that it may be and often is a carrier of a wisdom of entanglement that is essential and hard to capture through established schemes of planning and decision-making. Still, this wisdom seems to be more in line with sustainability and a sound human-earth relationship than the most elaborate impact models assessments. However, it is hard to know what to do with it. To use an awkward phrase: these are insights that are hard to operationalize. It took a full four hundred years from the early pioneers of private property rights and sovereignty theory in the Early Modern period to create and cement a system like the one we have now. Emotions represent a helpful source of insight in the work to correct it. Certainly not the only one, but one that will have to weigh into the work of reforming our collective, societal deliberation on resource extraction.

\section{Emotion and environment are connected}

Back now to the wider framing conditions that make these papers in themselves part of an ongoing change. One thing they share in common is how well they are aware that mining conflicts are no longer the same as they were. Some simple facts and framing conditions on the ground have changed. There is a new Finnmark Law in Norway, and there is Greenland Self-Government. There is higher visibility for indigenous rights. Despite their shortcomings, impact analyses are after all required. On the other hand, deregulation and decentralization over the past several decades have changed the rules of the game giving a tail wind to pro-extractive forces. This has gone hand in hand with globalization, allowing for more boom and bust. This speaks for careful empirical work to determine what outcomes have been.

Possibly a very large shift over the long term is the temporalization of extractive industries in the context of a narrative of the human-earth relationship and the planet as a whole. Extraction of fossil fuels has an uncertain future, to say the least. Mining is also uncertain. It is dependent on so many uncertain, fully possible factors, including substitution with new materials and local resistance - but also continued growth in a soon ten billion people world with massive rise of material circulation and extraction; essentially an unabated continuation of the Great Acceleration. At present, some metals, such as rare earths, are on the rise. Other minerals, such as iron and coal, are stagnating. This is not the place to investigate these prospects further. Whatever the trends, there is a case to be made for the Arctic as a region where caution and care in the engagement of extractive industries are probably a wise approach under the circumstances.

Linking emotions and environment is also an example of what Marianne Lien talks about as "destabilizing" the concepts. "The environment" with its rich conceptual history (Selcer, 2018; Warde \& Sörlin, 2015; Warde et al., 2018), linked to science, policy, diplomacy, and multiple strands of expertise is here combined with a more subjective take that offers new openings. The most articulate language on this topic is offered by Hedda Askland (2021) discussing Australian extraction towns. Environment, too, she reminds us, is an emotional space, where "the human body, mind, emotion and environment are interconnected." In other words, "[p] eople extend out into their environment and the environment extends into them," she suggests (citing Marshall \& Connor, 2016:2).

To Askland environments should be understood as an extension of connections between humans and their "lifeworlds." She 
thus sets in motion Jürgen Habermas' concept with its repercussions from Edmund Husserl (Fairtlough, 1991). Hers is also a Batesonian (1972) approach, toward an "ecology of mind." This seems to me an important qualifier of the affective turn, suggesting ontological standing and empirical anchoring of emotions not just in the individual's brain but in human connections. Habermas' lifeworld concept is, after all, part of a theory of human action understood as fundamentally possible and based on an idea of trust in language and communication. The title of his two-volume sociological classic on the subject was Theorie des kommunikativen Handelns, translated as A Theory of Communicative Action (Habermas, 1981/1984-1987). This theory rests on our human abilities to establish relations between each other and with our lifeworlds in their totality. The title of its volume II speaks to the most fundamental and fruitful undercurrent that I have found in these Arctic Uchronotopia papers: Lifeworld and System: A Critique of Functionalist Reason. Affect can learn from both lifeworlds and systems thinking. It can critique and temper "functionalist reason." It can possibly also learn to cooperate with it.

Widening the idea of affect to include its relationship with the environment as an "extension of connections" also opens the doors toward a less solipsistic and subjective understanding of affect. Instead, it proposes that affect is in principle possible to integrate with science-based readings of landscapes and lifeworlds that may otherwise always be the problematic "other" in affective discourse. These, potential, relations between the personal, experience-based emotional register and the socio-cultural-ecological one seem to me both possible and urgent to investigate further. These eminent articles have already started this work

Acknowledgements. Work toward this article has been supported by REXSAC, Resource Extraction and Sustainable Arctic Communities, a collaborative and interdisciplinary Center of Excellence funded by Nordforsk (Oslo) and hosted by the Division of History of Science, Technology and Environment at the KTH Royal Institute of Technology, Stockholm.

Conflicts of interest. I have no conflicts of interest.

\section{References}

Adeney Thomas, J., Walters, M., \& Zalasiewicz, J. (2020). The Anthropocene: A Multidisciplinary Approach. Cambridge: Polity.

Ahmed, S. (2010). The Promise of Happiness. Durham, NC: Duke University Press.

Allen, I. K. (2020). Thinking with a Feminist Political Ecology of Air-andbreathing-bodies. Body \& Society, 26(2), 79-105. doi: 10.1177/ 1357034X19900526

Allen, I. K. (2021, forthcoming). Dirty Coal: Populism as purification in Poland's mining heartland. $\mathrm{PhD}$ dissertation. Division of History of Science, Technology and Environment, KTH Royal Institute of Technology, Stockholm.

Anderson, B. (1983). Imagined Communities: Reflections on the Origin and Spread of Nationalism. London: Verso.

Arctic Today. (2020). Trump administration plans for early January sale of Arctic refuge oil releases. December 3. https://www.arctictoday.com/ trump-administration-plans-for-early-january-sale-of-arctic-refuge-oilleases/

Askland H. H. (2021, this issue). Mining voids: Extraction and emotion at the Australian coal frontier. Polar Record 56(e5): 1-10. doi: https://doi.org/ $10.1017 / S 0032247420000078$

Avango, D., \& Kramvig, B. (2021, this issue). Gollegiisá - The Treasure Chamber. Polar Record 56.

Avango, D., Nilsson, A. E., \& Roberts, P. (2013). Assessing arctic futures: Voices, resources and governance. The Polar Journal, 3(2), 431-446.
Avango, D., \& Roberts, P. (2017). Industrial Heritage and Arctic Mining Sites: Material Remains as Resources for the Present - and the Future. In R. C. Thomsen, \& L. R. Bjørst (Eds.), Heritage and Change in the Arctic: Resources for the Present, and the Future. Aalborg: Aalborg Universitetsforlag.

Bateson, G. (1972). Steps to an ecology of mind: Collected essays in anthropology, psychiatry, evolution and epistemology. Chicago, IL: University of Chicago Press.

Bauman, Z. (2001). Community: Seeking Safety in an Insecure World. Cambridge, UK: Polity Press.

Bjørst L. R. (2021, this issue). Stories, emotions, partnerships and the quest for stable relationships in the Greenlandic mining sector. Polar Record, 56(e23), 1-13. doi: https://doi.org/10.1017/S003224742000 0261.

Bridge, G. (2009). Material Worlds: Natural resources, resource geography and the material economy. Geography Compass, 3(3), 1217-1244.

Broberg, G., \& Roll-Hansen, N. (1996). Eugenics and the Welfare State. East Lansing, MI: Michigan State University Press.

Bromé J. (1923). Nasafjäll: Ett norrländskt silververks historia. Stockholm: Nordiska bokhandeln.

Childs, J. (2016). Geography and resource nationalism: A critical review and reframing. Extractive Resources and Society, 3(2), 539-546.

Clough, P. T., \& Halley, J. (2007). The Affective Turn: Theorizing the Social. Durham, NC: Duke University Press.

Coates, K. (2018). The history and historiography of natural resource development in the Arctic: The state of the literature. In C. Southcott, F. Abele, D. Natcher, \& B. Parlee (Eds.), Resources and Sustainable Development in the Arctic. London: Routledge.

Cruikshank, J. (2005). Do Glaciers Listen?: Local Knowledge, Colonial Encounters, and Social Imagination. Vancouver: University of British Columbia Press.

De Gregori, T. (1987). Resources are not; they become: An institutional theory. Journal of Economic Issues, 21(3), 1241-1263. http://www.jstor.org/stable/ 4225924

Delanty, G. (2002). Community. London: Routledge.

Ebbesson, J. (2020/2021). Klimatprocesser mot staten - runt om i världen och i Sverige. Juridisk Tidskrift, 32(1), 106-129.

Ernstson, H., \& Sörlin, S. (2013) Ecosystem services as technology of globalization: On articulating values in urban nature. Ecological Economics 86, 273284. DOI: $10.1016 /$ j.ecolecon.2012.1009.1012

Fairtlough, G. H. (1991). Habermas' concept of "Lifeworld". Systems Practice, 4, 547-563.

Fleming, P. (2015). The art of flirtation: Simmel's coquetry without end. In D. Hoffman-Schwartz, B. N. Nagel, \& L. S. Stone (Eds.), Flirtations: Rhetoric and Aesthetics This Side of Seduction (pp. 19-30). New York: Fordham University Press.

Fondahl, G., \& Wilson, G. N. (Eds.). (2017). Northern Sustainabilities: Understanding and Addressing Change in the Circumpolar World. Cham: Springer Nature.

Franklin, S. (1997). Embodied Progress: A Cultural Account of Reproduction. London: Routledge.

Freeman, R. E., Pierce, J., \& Dodd, R. H. (2000). Environmentalism and the New Logic of Business: How Firms Can be Profitable and Leave Our Children a Living Planet. Oxford: Oxford University Press.

Fur, G. (2013). Colonialism and Swedish history: Unthinkable connections? In M. Naum, \& J. M. Nordin (Eds.), Scandinavian Colonialism and the Rise of Modernity: Small Time Agents in a Global Arena (pp. 17-36). New York: Springer.

Fur, G., \& Hennessey, J. (2020). Introduktion: Svensk kolonialism, Sverige och kolonialism eller svenskar och kolonialism? Historisk Tidskrift, 140(4), 375-384.

Gaski, H. (1993). The Sami People: The 'White Indians' of Scandinavia. American Indian Culture and Research Journal, 17, 115-128.

Gilroy, P. (2005). Postcolonial Melancholia. New York, NY: Columbia University Press.

Glassheim, E. (2016). Cleansing the Czechoslovak Borderlands: Migration, Environment, and Health in the Former Sudetenland. Pittsburgh, PA: University of Pittsburgh Press. 
Habermas, J. (1981). Theorie des kommunikativen Handelns. (Vol. 1: Handlungsrationalität und gesellschaftliche Rationalisierung, Vol. 2: Zur Kritik der funktionalistischen Vernunft). Frankfurt am Main: Suhrkamp. English translation, Thomas A. McCarthy (1984-1987): Theory of Communicative Action (Vol. 1: Reason and the Rationalization of Society, Vol. 2: Lifeworld and System: A Critique of Functionalist Reason). Boston, MA: Beacon Press.

Haikola, S., \& Anshelm, J. (2019). Evolutionary governance in mining: Boom and bust in peripheral communities in Sweden. Land Use Policy, 93, April. https://doi.org/10.1016/j.landusepol.2019.104056

Hays, S. P. (1959). Conservation and the Gospel of Efficiency: The Progressive Conservation Movement, 1890-1920. Cambridge, MA: Harvard University Press.

Hoffman-Schwartz, D., Nagel, B. N., \& Stone, L. S. (2015). Flirtations: Rhetoric and Aesthetics This Side of Seduction. New York: Fordham University Press.

Hörisch, J., Freeman, R. E., \& Schaltegger, S. (2014). Applying stakeholder theory in sustainability management: Links, similarities, dissimilarities, and a conceptual framework. Organization \& Environment, 27(4), 328346. doi: $10.1177 / 1086026614535786$

Hylland Eriksen, T. (2016). Overheating: An Anthropology of Accelerated Change. London: Pluto Press.

Hylland Eriksen, T. (2018). Boomtown: Runaway Globalisation on the Queensland Coast. London: Pluto Press.

Jarvis, B. (2019). Climate change could destroy his home in Peru: So he sued an energy company in Germany. New York Times Magazine, 9 April.

Jørgensen, A.-M. (2021, this issue). Communitification and emotional capital: Producing, shaping and re-shaping communities before and after mining in Norrbotten and Disko Bay. Polar Record, 56(e7), 1-11. doi: https://doi.org/ 10.1017/S0032247419000548

Josephson, P. (2014). The Conquest of the Russian Arctic. Cambridge, MA: Harvard University Press.

Keeling, A., \& J. Sandlos (Eds.). (2015). Mining and Communities in Northern Canada: History, Politics, and Memory. Calgary: University of Calgary Press.

Koivurova T., Lesser P., Bickford S., Kankaanpää P., \& Nenasheva M. (2016). Environmental Impact Assessment in the Arctic: A Guide to Best Practice. Cheltenham: Edward Elgar.

Koselleck, R. (1979). Vergangene Zukunft: Zur Senmantik Geschichtlicher Zeiten. Frankfurt am Main: Suhrkamp Verlag.

Koselleck, R. (2002). The Practice of Conceptual History: Timing History, Spacing Concepts. (T. Presner, K. Behnke \& J. Welge, Trans.). Stanford, CA: Stanford University Press.

Larsen, R. K., \& Nilsson, A. E. (2017). Knowledge production and environmental conflict: Managing systematic reviews and maps for constructive outcomes. Environmental Evidence, 6, 17. https://doi.org/10.1186/s13750-0170095-X

Larsen, R. K., Raitio, K., Stinnerbom, M., \& Wik-Karlsson, J. (2017). Samistate collaboration in the governance of cumulative effects assessment: A critical action research approach. Environmental Impact Assessment Review, 64, 67-76.

Lawrence, R., \& Åhrén, M. (2016). Mining as colonisation: The need for restorative justice and restitution of traditional Sami lands. In L. Head, S. Saltzman, G. Setten, \& M. Stenseke (Eds.), Nature, Temporality and Environmental Management: Scandinavian and Australian Perspectives on Landscapes and Peoples. London: Taylor \& Francis.

Lawrence, R., \& Larsen, R. K. (2017). The politics of planning: Assessing the impacts of mining on Saami lands. Third World Quarterly, 38, 1164-1180.

Lien, M. E. (2021, this issue). Interruptions: Affective futures and uncanny presences at Giemaš, Finnmark. Polar Record, 57(e1), 1-9. https://doi.org/10. 1017/S0032247420000443

Magnusson, L. (2015). The Political Economy of Mercantilism. Abingdon, Oxon: Routledge.

Marshall, J. P., \& Connor, L. H. (Eds.). (2016). Environmental Change and the World's Futures. Ecologies, Ontologies and Mythologies. Oxon and New York: Routledge.

McCannon, J. (2012). A History of the Arctic: Nature, Exploration and Exploitation. London: Reaktion Books.
Naum, M., \& Nordin, J. M. (Eds.). (2013). Scandinavian Colonialism and the Rise of Modernity: Small Time Agents in a Global Arena. New York: Springer.

Nordin, J. M., \& Ojala, C.-G. (2015). Mining Sápmi: Colonial histories, Sámi archaeology, and the exploitation of natural resources in Northern Sweden. Arctic Anthropology, 52(2), 6-21.

Nordin, J. M., \& Ojala, C.-G. (2020). An industrial revolution in an Indigenous landscape: The copper extraction of the early modern Torne River valley in its global context. Fennoscandia Archaeologica, 37, 61-81.

Novikova, N. (2017). Legal framework for extractive industries and indigenous peoples in the Russian North. Ájluokta/Drag, Norway: Árran Lule Sami Centre.

Nuttall, M. (1998). Protecting the Arctic: Indigenous Peoples and Cultural Survival. Abingdon, Oxon: Routledge. https://www.routledge.com/ Protecting-the-Arctic-Indigenous-Peoples-and-Cultural-Survival/Nuttall/ p/book/9789057023552

Nuttall, M. (2017). Climate and Subsurface Politics in Greenland: Under the Great Ice. Abingdon, Oxon: Routledge. https://www.routledge.com/ Climate-Society-and-Subsurface-Politics-in-Greenland-Under-the-Great/ Nuttall/p/book/9781138820517

Oppenheimer M., Oreskes, N., Jamieson D., Brysse K., O'Reilly J., Shindell M., \& Sazeck, M. (2019). Discerning Experts: The Practices of Scientific Assessment for Environmental Policy. Chicago, IL: The University of Chicago Press.

Österlin, C., \& Raitio, K. (2020). Fragmented Landscapes and PlanscapesThe Double Pressure of Increasing Natural Resource Exploitation on Indigenous Sámi Lands in Northern Sweden. Resources 9(9), 104.

Overland, I. (2016). Ranking oil, gas and mining companies on Indigenous rights in the Arctic. Ájluokta/Drag, Norway: Árran Lule Sami Centre. https://arran. no/sites/a/arran.no/files/arran_lule_ranking_core_paper2_web.pdf

Papillon, M., \& Rodon, T. (2017). Proponent-indigenous agreements and the implementation of the right to free, prior and informed consent in Canada. Environmental Impact Assessment Review, 62, 216-224.

Porter, T. M. (1995). Trust in Numbers: The Pursuit of Objectivity in Science and Public Life. Princeton, NJ: Princeton University Press.

Pritchard, S. B. (2012). An envirotechnical disaster: Nature, technology, and politics at Fukushima. Environmental History, 17(2), 219-243. https://doi. org/10.1093/envhis/ems021

Pryser Libell, H., \& Bryson Taylor, D. (2020). Norway's Supreme Court makes way for more Arctic drilling. New York Times 22 December. https://www. nytimes.com/2020/12/22/world/europe/norway-supreme-court-oil-climatechange.html

Retten, G.-B. (2021). Vi kaller det grønn kolonisering. Morgenbladet, 202(2). https://morgenbladet.no/ideer/2021/01/vi-kaller-det-gronn-kolonisering

Riseth, J. Å., Solbakken, I., \& Kitti, H. (2010). Naturbruk i Kautokeino: Fastboendes bruk av Meahcci i Kautokeino kommune og konsekvenser ved etablering av naturvernområder. Kautokeino: Sami Allaskuvla.

Rosqvist, G., Inga, N., \& Eriksson, P. (2021). Impacts of climate warming on reindeer husbandry demand new land use strategies (in review).

Schulz-Forberg, H. (2013). Introduction: Time and again towards the future: Claims on time as a new approach for global history. In H. Schulz-Forberg, (Ed.), Zero Hours: Conceptual Insecurities and New Beginnings in the Interwar Period. Brussels: P.I.E.-Peter Lang.

Sejersen, F. (2021, this issue). Brokers of hope: Extractive industries and the dynamics of future-making in post-colonial Greenland. Polar Record, 56(e22), 1-11. doi: https://doi.org/10.1017/S0032247419000457

Selcer, P. (2018). The Postwar Origins of the Global Environment: How the United Nations Built Spaceship Earth. New York: Columbia University Press.

Seyfert, R. (2012). Beyond personal feelings and collective emotions: A theory of social affect. Theory, Culture \& Society, 29(6), 35. doi: 10.1177/ 0263276412438591

Sörlin, S. (1988). Framtidslandet: Debatten om Norrland och naturresurserna under det industriella genombrottet, 1870-1920. [With a summary in English: Land of the Future: The Debate on the North and Natural Resources during the industrial breakthrough, 1870-1920.] Stockholm: Carlsson.

Sörlin, S. (2017). The Arctic Ocean. In D. Armitage, A. O. Bashford, \& S. Sivasundaram (Eds.), Oceanic Histories (pp. 269-295). Cambridge: Cambridge University Press. 
Sörlin, S. (2018). Anthropocene Arctic: Reductionist Imaginaries of a 'New North'. In N. Wormbs (Ed.), Competing Artic Futures: Historical and Contemporary Perspectives (pp. 243-269). New York: Palgrave Macmillan.

Sörlin, S. (2021). Is there such a thing as 'Best Practice'?: Exploring the extraction/sustainability dilemma in the Arctic. In Douglas C. Nord (Ed.), Nordic Perspectives on the Responsible Development of the Arctic: Pathways to Action (pp. 321-348). Cham: Springer Nature. doi: 10. 1007/978-3-030-52324-4_15.

Steffen, W., Richardson, K., Rockström, J., Cornell, S. E., Fetzer, I., Bennett, E. M., .. . S. Sörlin. (2015). Planetary boundaries: Guiding human development on a changing planet, Science, 347(6223), 736-746.

Thisted K. (2021, this issue). Emotions, finances and independence: Uranium as a "happy object" in the Greenlandic debate on secession from Denmark. Polar Record, 56(e1), 1-12. doi: https://doi.org/10.1017/S003 2247419000433

Thisted, K., Sejersen, F., \& Lien, M. E. (2021, this issue). Introduction. Polar Record, 56(e1).

Tsing, A. L. (2000). Inside the Economy of Appearances. Public Culture 12(1): 115-144.

Warde, P., Robin, L., \& Sörlin, S. (2018). The Environment: A History of the Idea. Baltimore, MD: Johns Hopkins University Press.

Warde, P., \& Sörlin, S. (2015). Expertise for the Future: The Emergence of Environmental Prediction c. 1920-1970. In J. Andersson \& E. Rindzeviciute (Eds.), The Struggle for the Long Term in Transnational Science and Politics: Forging the Future (pp. 38-62). Abingdon: Routledge.

Ween, G. (2021, this issue). The map machine: Salmon, Sámi, sand eels, sand, water and reindeer: Resource extraction in the High North and collateral landscapes. Polar Record, 56(e19), 1-10. doi: https://doi.org/10.1017/ S0032247420000236

Ween, G., \& Lien, M. (2012). Decolonialization in the Arctic?: Nature practices and land rights in the Norwegian High North. Journal of Rural and Community Development, 7(1), 93-109.

Wendel-Hansen, J. L. (2019). How Donald Trump's proposal to buy Greenland really went down in Denmark. The Conversation 23 August https:// theconversation.com/how-donald-trumps-proposal-to-buy-greenlandreally-went-down-in-denmark-122160.

Wetherell, M. (2012). Introducing affect: Lines of argument. In M. Wetherell (Ed.), Affect and Emotion: A New Social Science Understanding (pp. 1-26). Los Angeles \& London: SAGE.

Wilson, E. and Stammler, F. (2016) Beyond extractivism and alternative cosmologies: Arctic communities and extractive industries in uncertain times. Introduction to: Arctic Voices: Expectations, Narratives and the Realities of Living with Extractive industries in the Far North. Wilson, E., \& Stammler, F. (Eds.). Special section of Extractive Industries and Society $3(1), 1-8$.

Wormbs, N. (Ed.). (2018). Competing Artic Futures: Historical and Contemporary Perspectives. New York: Palgrave Macmillan.

Wormbs, N., \& Sörlin, S. (2017). Arctic Futures: Agency and Assessing Assessments. In L.-A. Körber, S. MacKenzie, \& A. Westerståhl Stenport (Eds.), Arctic Environmental Modernities from the Age of Polar Exploration to the Era of the Anthropocene (pp. 263-285). London: Palgrave Macmillan.

Zimmermann, E. (1933). World Resources and Industries: A Functional Appraisal of the Availability of Agricultural and Industrial Resources. New York: Harper \& Brothers. 